\title{
衝突面にリブを付加した二次元衝突噴流冷却に関する直接数值計算 DNS of Two-Dimensional Jet Impingement Cooling on Target Surface with a Rib
}

\author{
○正 小田 豊（阪大）＼cjkstart正 武石 賢一郎（阪大） \\ Yutaka Oda and Kenichiro Takeishi \\ Osaka University, 2-1, Yamadaoka, Suita, Osaka 565-0871
}

\begin{abstract}
Two-dimensional jet impingement heat transfer enhanced by a square rib has been studied by direct numerical simulation (DNS) to compare predicted Nusselt number with that given by naphthalene sublimation method. In addition to Prandtl number (Pr) of 0.71 for air, Pr of 2.29 equivalent to the Schmidt number in the mass transfer experiment was selected for comparison. The DNSs with different Pr numbers give the local value of the exponent, which is assumed uniform in the conversion of mass transfer coefficient to heat transfer coefficient in the experiments. As a result, it is clarified that the local discrepancy of Nusselt number between the former experiments and simulations has come from the assumption of uniform exponent in the mass transfer experiment.
\end{abstract}

Key Words: Jet Impingement, DNS, Naphthalene Sublimation, Heat/Mass Transfer Analogy

\section{1. 緒言}

淀み点で高い熱伝達率が得られる衝突噴流冷却は高温ガ スタービンの翼冷却や電子機器の冷却などに広く利用され ている。しかしながら，淀み点から離れた壁噴流領域に入 ると熱伝達率が急激に低下する欠点があるため, 壁噴流領 域における効果的な伝熱促進手法の開発が望まれている. そこで我々は，壁噴流領域に乱流促進体となる突起物（リ ブ）を設けて壁噴流の剥離・再付着を促すことで, より広 い範囲で熱伝達率を向上させる手法に着目し, 第一段階と して二次元噴流を対象とした研究を行い, 熱・物質輸送の 相似性に基づくナフタレン昇華法や RANS, LES を用いて リブ高さやリブの位置が熱伝達に与える影響について検討 を行ってきた(1),(2).しかし，これらの研究ではリブ下流の 再付着点付近における平均ヌセルト数が, RANS, LES で は実験に比べて過小評価される傾向があった. そこで本研 究では, 乱流モデルによる誤差を排除できるDNS（直接数 值計算）をリブ周辺の熱流動場に適用し，数值解析におけ る過小評価の原因を明らかにすることを試みたので，その 結果を報告する。

\section{2. 直接数值計算 (DNS) の概要}

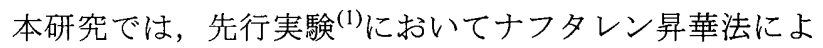

り取得した時間平均熱伝達率の詳細な分布との比較を念頭 に置き，その二次元衝突噴流に関する実験系を模擬した解 析系を対象に DNS 解析を実施した. 図 1 に解析領域の xy 断面々噴流衝突面の主要な寸法, 解析条件を示す。二次元 ノズル出口の幅 $B(=4 \mathrm{~mm})$ を基準とした衝突距離は $H=$ $10 B$ であり,ノズル出口幅と出口流速を基準とした Re 数は 5000 とした. また, 今回の DNS 解析ではリブの位置を噴 流衝突点から $L=20 \mathrm{~mm}$ に固定し, リブ高さ $e$ は $0.5 \mathrm{~mm}$ と した. なお，本解析にはマルチブロック構造格子系を適用 可能な内製コードを用いた。これにより，リブ周辺（図 1 の灰色部分）に高い空間解像度を有する構造格子ブロック を配置することが可能となり, 計算負荷を大幅に低減した. この際, リブ上流側に位置する構造格子ブロックの流入境 界条件が必要となる。このため, 本研究では基本となる背 景流れとして（リブ無しの）平板面に対する解析を併せて 実行し，リブ上流での流入境界条件を基本背景流れから補 間により時々刻々与えて計算を行った.

基礎式には，一般座標系における非圧縮性 Navier-Stokes 式, 連続の式, エネルギ式を用いた。解析手法には稲垣ら (3)の改良型二次精度コロケート格子に基づく Fractional Step 法を適用し, 時間発展には分子粘性項以外には二次精 度 $\mathrm{AB}$ 法を，分子粘性項には $\mathrm{CN}$ 法を適用した。移流項の

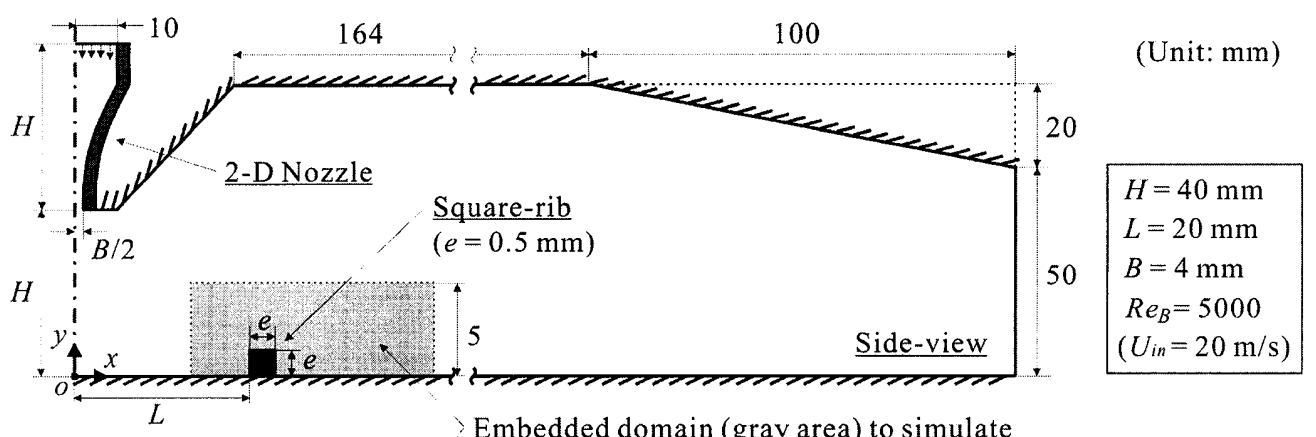

Embedded domain (gray area) to simulate

flow and heat transfer around a rib

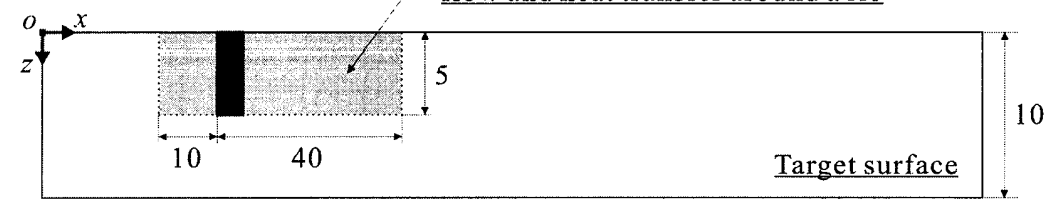

Fig. 1 Computational domain of DNS for the comparison with mass transfer experiment ${ }^{(1)}$. 


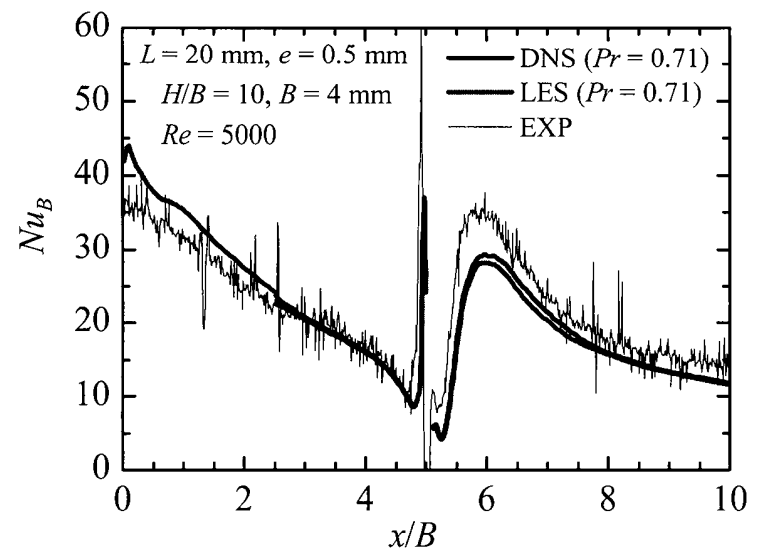

Fig. 2 Nusselt number distribution.

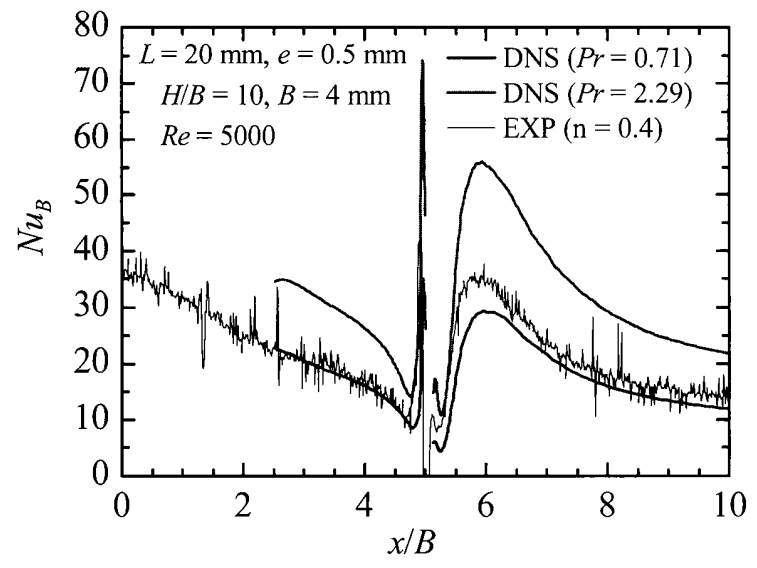

Fig. 3 Effect of Prandtl number on Nusselt number.

空間差分には自乗量保存型の二次精度中心差分を適用した. 速度場の境界条件としては， $x=0$ で対称条件，ノズル 入口で一様流速条件, 壁面で滑り無し条件, 流出境界では 対流流出条件を用いた。温度場については，ノズル入口で 一様温度 $300 \mathrm{~K}$, 比較実験でナフタレン層を形成した底面

（リブ表面は除く）では $330 \mathrm{~K}$ の等温条件を与え，リブ表 面を含むその他の壁面は断熱条件とした。また，ナフタレ ン昇華法 $(S c=2.29, L e=3.21)$ の濃度場を温度場で模擬した 解析を行うため, $P r=0.71,2.29$ の条件で DNS を行った。

\section{3. 結果と考察}

図 2 は, $P r=0.71$ DNS で得た噴流衝突面上の局所平 均ヌセルト数を，既報 ${ }^{(1),(2)}$ で実施した実験と LES の結果と 比較したものである．DNS と LES の結果は定量的にも良 い一致を示しているが，再付着点付近では DNS が LESよ りも少し高い值を示している。これは LES の温度場には TVD 法を適用していた事が原因と思われる。また，DNS， LES ともに再付着点付近では実験值を過小評価しているこ とが分かる．ナフタレン昇華法では，熱・物質輸送の相似 性に基づき, $h=h_{D} \rho C_{p}(S c / P r)^{1-n}$ の関係式を用いて物質伝 達率 $h_{D}$ を熱伝達率 $h$ に変換している.この式はルイス数 $L e(=S c / P r)$ が 1 に近い場合に近似的に下記の関係が成立す ることに由来する。

$$
N u=\frac{h L}{\lambda}=c \operatorname{Re}^{m} \operatorname{Pr}^{n} \approx S h=\frac{h_{D} L}{D}=c \operatorname{Re}^{m} S c^{n}
$$

上式に現れる指数 $\mathrm{n} に は$ 経験的な值が用いられ，乱流場で は $\mathrm{n}=0.4$ が推奨されている. しかしながら, 複雑な乱流場

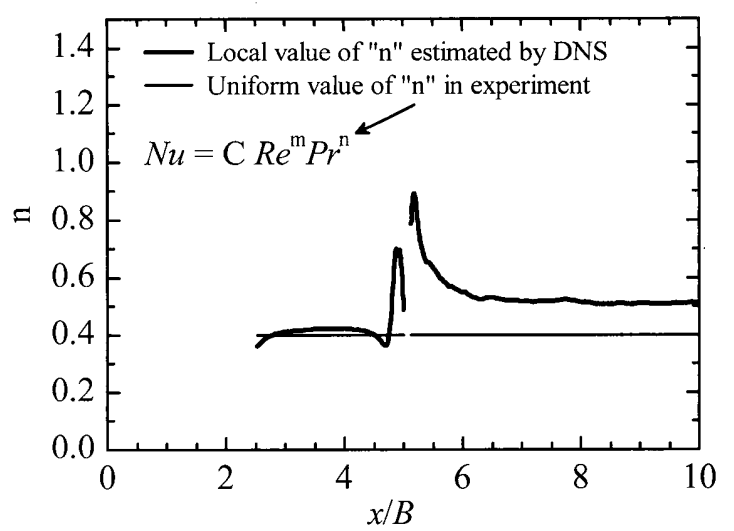

Fig. 4 Local exponent "n" estimated by DNS.

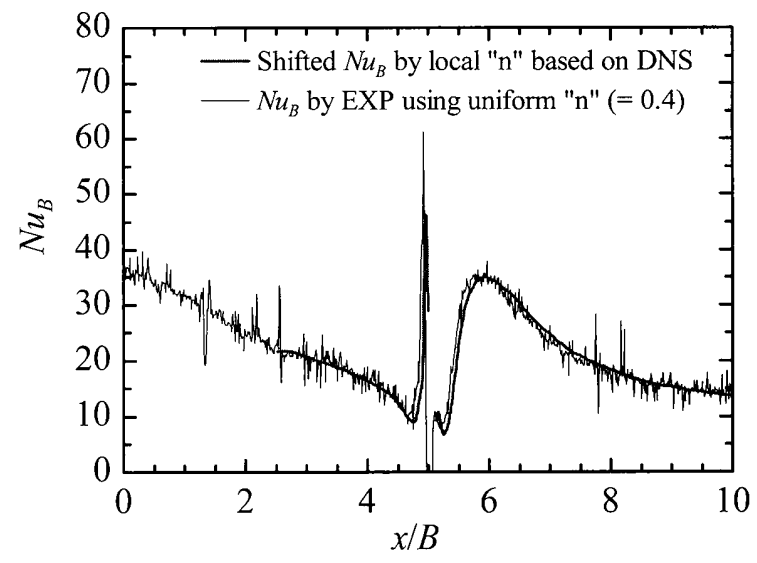

Fig. 5 Comparison of equivalent Nusselt number.

ではnの值が系全体で一様になるとは限らず，そのことが 実験と解析の誤差を生む原因になる可能性がある。これを 確かめるため, $\operatorname{Pr}_{(1)}=0.71, \operatorname{Pr}_{(2)}=2.29$ の条件で得た $N u_{(1)}$, $N u_{(2)}$ を用いて次式により局所における $\mathrm{n}$ の值を算出した.

$$
n=\ln \left(\frac{N u_{(1)}}{N u_{(2)}}\right) / \ln \left(\frac{\operatorname{Pr}_{(1)}}{\operatorname{Pr}_{(2)}}\right)
$$

図 3 は, プラントル数がヌセルト数に与える影響を示し たものであり，ここで示された各プラントル数におけるヌ セルト数の分布を用いて, 式(2)より局所の指数 $\mathrm{n}$ を算出し た值を図 4 に示している.これより, リブ上流では $\mathrm{n}=0.4$ に近い值を示す一方で，リブ近傍および下流では異なる值 を示すことが分かり，本実験系では指数 $\mathrm{n}$ に一様な值を与 えるのは適切でないことが分かる. 図 5 は図 4 で得た指数 $\mathrm{n}$ の分布に基づいてDNSの結果から実験と等価なヌセルト 数を算出し，両者の值を比較したものである.これより， 適切な指数 $\mathrm{n}$ を与えると, 実験と DNS の結果が再付着点付 近も含めて全域で非常に良い一致を示すことが分かった。 以上より, 従来の実験と数值解析の比較で見られた再付着 点付近でのヌセルト数の差異は, 物質伝達率から熱伝達率 に変換する際，指数 $\mathrm{n}$ に系全体で一様な值を与えていたこ とが原因であることが明らかになった。

\section{参考文献}

(1) 小田ら, スマートプロセス学会誌, Vol.2, No.5 (2013).

(2) 小田・武石, スマートプロセス学会誌, Vol.2, No.5 (2013).

(3) 稲垣ら, 機論 B 編, 64 (1998), 1981. 